\title{
The Clinical Rehabilitation and Cathepsin K Gene Analysis of a Turkish Family With Pycnodysostosis
}

\author{
Piknodizostozis Sendromlu Bir Türk Ailenin Klinik Rehabilitasyonu ve Katepsin K Geni \\ Analizi
}

Belen ŞİRINOĞLU ÇAPAN ${ }^{~}$; Korkut ULUCAN ${ }^{2}$; Serap AKYÜZ ${ }^{3}$

\begin{abstract}
Pycnodysostosis (PKND) is a rare, autosomal recessive disease characterized by short stature, severe bone fragility exophthalmus and oral manifestations such as micrognathia. It usually demonstrates typical craniofacial deformities, such as hypoplastic midface, anterior cross-bite, grooved palate and dental crowding. The aim of this case report is to report the rehabilitation and analyze the cathepsin $K$ for pycnodysostosis under reported cases of three siblings with PKND. A family with 5 siblings, 3 effected and 2 non - effected, were examined clinically and radiologically, and restorative treatments and protective applications were carried out in the effected members. To clarify the underlying reason, cathepsin $K$ was amplified and sequenced directly by using specific primers. All the affected members carried L 7P variation as homozygous state, whereas unaffected had the heterozygous state of the same condition. Early diagnosis and treatment is important with PKND patients, since bone fractures easily occur during dental treatment and limited mouth opening makes it difficult to access the treated area. Frequent recalls should be planned for PKND patients. Regular oral care and early preventive treatments ensure the patients a better life quality. Also, we suggest that L7P variation of cathepsin $K$ may be a diagnostic criterion for PKND. Keywords: Pycnodysostosis, cathepsin K, clinic, genetic
\end{abstract}

\footnotetext{
${ }^{2}$ Korkut Ulucan (凶)

${ }^{2}$ Correspondance: Dr. Korkut Ulucan, Marmara University, Faculty of Dentistry, Buyukciftlik Sok. No: 6, Guzelbahce, Nisantasi, Istanbul, Turkey, 34365

Marmara University, Faculty of Dentistry, Department of Basic Medical Sciences, Division of Medical Biology and Genetics, Istanbul, Turkey korkut.ulucan@marmara.edu.tr,

Belen Şirinoğlu Çapan ${ }^{1}$;

${ }^{1}$ Biruni University, Faculty of Dentistry, Department of Pediatric Dentistry, Istanbul, Turkey

${ }^{3}$ Serap Akyüz

Marmara University, Faculty of Dentistry, Department of Pediatric Dentistry, Istanbul, Turkey
}

Tel:02122319120, Fax:02122465247

Submitted / Gönderilme: 13.03 .2018

Accepted/Kabul: 02.04.2018
Öz

Psikositozis (PKND), kısa boy, şiddetli kemik kırılganlı̆̆g, ekzoftalmi ve mikrognati gibi oral belirtilerle karakterize, nadir görülen, otozomal resesif bir hastalıktır. Genellikle hipoplastik orta yüz, ön çapraz kapanış, derin damak ve dental çapraşıklık gibi tipik kraniyofasiyal deformiteler ile görülür. $\mathrm{Bu}$ olgu sunumunun amac1, PKND'li üç kardeşin dental tedavilerini sunmak ve bildirilen vakalar altında pycnodysostosis için Katepsin K'y1 analiz etmektir. Kliniğimize başvuran ailenin 5 çocuğundan üçünde piknodizostosis görülürken, diğer iki kardeş sağlıklıydı. Çocukların detaylı klinik ve radyolojik muayeneleri yapıldıktan sonra etkilenen bireylerin gerekli restoratif ve koruyucu tedavileri tamamland1. Altta yatan nedeni açığa çıkarmak amacıyla, Katepsin $\mathrm{K}$ amplifiye edildi ve spesifik primerler kullanılarak doğrudan sekansland1. Etkilenen tüm kardeşler homozigot bir durum olarak L7P varyasyonu taşırken, sağlıklı kardeşlerde ise aynı durumun heterozigot hali gözlendi. Piknodizostozis sendromlu hastalarda kemik kırıklarının kolay oluşması ve tedaviler için erişimi zorlaştıran sınırlı ağız açıklıkları nedeniyle erken tanı ve müdahale oldukça önemlidir. PKND hastaları için sık kontroller planlanmalıdır. Düzenli ağız bakımı ve koruyucu tedavilerin erken dönemde yapılması hastalara daha iyi bir yaşam kalitesi sağlamaktadır. Katepsin K'nın L7P varyasyonunun PKND için bir tanı kriteri olabileceğini düşünmekteyiz.

Anahtar Kelimeler: Piknodizostozis, katepsin K, klinik, genetik

\section{Introduction}

Pycnodysostosis (PKND) (OMIM 265800) is a rare, autosomal recessive disease characterized by short stature, total/partial dysplasia of the terminal phalanges, severe bone fragility, exophthalmos, beaked nose and oral manifestations such as micrognathia. It was first described by Maroteaux and Lamy in 1962. It belongs to the group of craniotubular bone dysplasias, as a form of dwarfism with craniofacial malformation similar to cleidocranial dysplasia 
$(1,2)$. PKND has an estimated incidence of 1.7 per 1 million births, without predilection for gender. It can be associated to consanguinity between the parents in $30 \%$ of cases $(3,4)$.

The gene responsible for the PKND, cathepsin K (CTSK) (MIM\# 601105), lies on 1q21, has 8 exons and 7 introns (5). Protein product of the gene, Cathepsin $\mathrm{K}$, is a lysosomal cysteine protease and has major roles in osteoclast-driven bone resorption, degradation of type I and type II collagens, osteopontin, and osteonectin (6). Many mutations affect the mature active domain of CTSK protein and caused CTSK deficiency because of the abnormal degradation of bone matrix proteins (7). As a result, high bone density and decreased bone turnover occurs. Because of sclerotic and fragile bones, most individuals affected by PKND have a history of recurrent fractures of the long bones. Pycnodysostosis is usually diagnosed at an early age due to the typical phenotype with proportionate dwarfism and peculiar facies $(1,3)$.

Pycnodysostosis usually demonstrates typical craniofacial deformities, such as hypoplastic midface, obtused mandibular gonial angle, anterior cross-bite and grooved palate. Intraoral features include delayed exfoliation of deciduous teeth, tooth misalignment and dental crowding. Dental crowding, hinders good oral hygiene leading to a high rate of caries and periodontal disease in these patients. In addition, enamel hypoplasia, and obliterated pulp chambers have been observed. Because of several morphological changes of maxillofacial structures PKND patients requiring specialized dental care (8-10).

Clinical manifestations of this syndrome are the main source of diagnosis. Comprehensive dental treatment comprising full oral rehabilitation. Orthodontic and orthognathic treatment becomes a challenge because of the reduced bone turnover of PKND (11).

The aim of this case report is to examine the CTSK for the onset of pycnodysostosis under reported cases, and discuss the presented management issues of PKND patients.

\section{Case Reports}

Three of five siblings (FE 16(ㅇ), ME 10(ㅇ) , HE 4(ㅇ)) with PKND applied to Marmara University, Faculty of Dentistry, Department of Pediatric Dentistry, Istanbul, Turkey. The other two siblings (AE $14\left(\delta^{\Uparrow}\right)$, ME 10(q)) were PKNDunaffected. Parents are healthy and they have consanguineous marriage. Patients did not show disturbances of behavior or sociability. All the siblings' detailed clinical and radiological examination was performed.

\section{- Case 1 -}

A 16 year old female patient, short stature, diagnosed with PKND at the age of 4 , based on clinical features, including beaked nose and micrognatia. Extra-oral examination presents dystrophic fingernails, a slightly retrognathic, convex profile and mid-facial hypoplasia with proptosed eyes. According to the panoramic radiograph the maxillary right first premolar, mandibular left and right second premolars and all third molars were congenitally absent. Both the maxilla and mandible were hypoplastic. and the mandibular angle was obtuse with prognathism. Intraoral examination revealed occlusal alterations, narrow and grooved palate, dental crowding, posterior cross bite and caries (Figure 1A and 1B). The periodontal examination of the patient composed of poor oral hygiene, visible plaque accumulation and gingival bleeding. Taking into consideration the fragility in these patients, appropriate restorative treatments and protective applications like fluoride or fissure sealant application were preferred. Patient was given oral hygiene education and recall visits occurred in every 3 months during the 18-month follow-up period (Figure 1C and 1D).
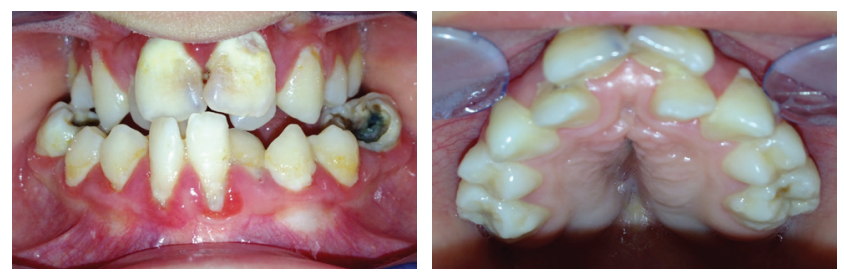

A B
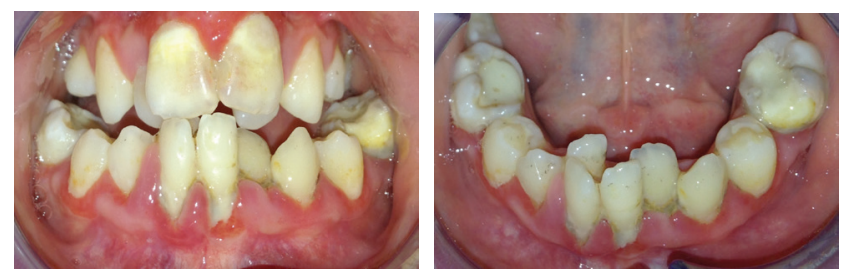

C

D

Figure 1: Frontal (A) and palatinal (B) view of Case 1 at first appointment, frontal (C) and occlusal (D) view after 18 - month follow-up.

\section{- Case 2 -}

A 10 year old female patient diagnosed with PKND, while her twin (ME) was not affected. She has short 
stature and presents facial asymmetry. The patient's main complaints were her facial appearance and tooth caries. Clinical examination of the patient presents short stature and retrognathic convex profile. Panoramic radiography showed maxillary left lateral incisor, all permanent second premolars and all third molars are congenitally absent. In intraoral examination, anterior cross-bite, grooved palate, delayed exfoliation of deciduous teeth, dental crowding, and caries observed (Figure 2A and 2B). Changes in gingival color and contour, edema, and very poor oral hygiene were present. These findings diagnosed as plaque-induced marginal gingivitis. The child brushed her own teeth once a day, without supervision from any adult. For a better oral hygiene the patient was given oral hygiene education. Restorative treatments of caries and treatment of marginal gingivitis are been completed. To provide the better oral hygiene protective treatments were made and recall visits occurred in every 3 months (Figure $2 \mathrm{C}$ and 2D).

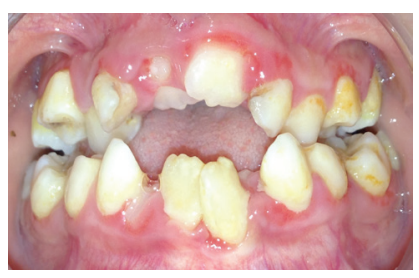

A

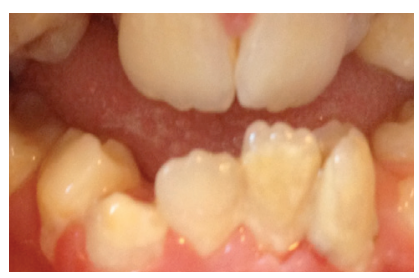

C

Figure 2: Frontal (A) and palatinal (B) view of Case 2 at first appointment, frontal (C) and occlusal (D) view after 18 - month follow-up.

\section{-Case 3 -}

A 4 year old female have been diagnosed with PKND at around 3 years of age, based on clinical manifestations, being the youngest of 3 affected siblings. The mother reported the similar aspects between the affected siblings after the second year, including that the child was small for her age and all the affected siblings presented similar facial features. Intraoral examination revealed grooved palate and dental caries. No features of enamel hypoplasia are seen in intraoral examination (Figure 3A and 3B). Panoramic radiography has not been taken because of her age. The patient is non-cooperative because of her age. Protective treatments and minimal invasive restorative treatments were preferred and recall visits revealed in every 3 months.
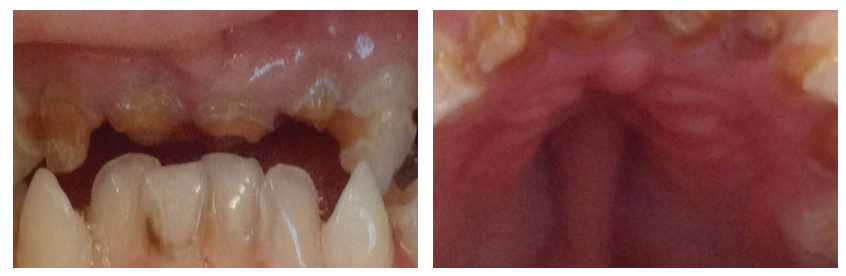

A

B

Figure 3: Frontal (A) and palatinal (B) view of Case 3 at first appointment.

\section{Genotyping}

To analyze CTSK in family members, genomic DNA was isolated from buccal cells by using "Buccal Amp ${ }^{\mathrm{TM}}$ DNA Extraction Kit”, by following manufacturer's instructions. Study protocol is in accordance with the principles of the Declaration of Helsinki II. Parents signed the informed consents prior to enrollment to the study. Primers and polymerase chain reaction conditions were carried out as previously described (5). Amplicons were sequenced by using ABI Prism Kit and on an Sanger autosequencer. Three of the siblings carried CC genotype, whereas 2 of the unaffected siblings and patients had CT genotype. $\mathrm{T}>\mathrm{C}$ transition at exon 2 leads the change of the amino acid leucine (L) to amino acid proline (P).

\section{Discussion}

Pycnodysostosis has a number of characteristic clinical and radiographic signs that differentiate it from other osteosclerotic conditions. General features include short stature, generalized diffuse osteosclerosis with a tendency for fracture after minimal trauma, and hypoplastic clavicles. Cranial and maxillofacial features include prominent eyes with blue sclerae, relative proptosis, beaked nose, frontoparietal bossing, open fontanelles and cranial sutures, hypoplastic paranasal sinuses, an obtuse mandibular gonial angle, often with relative prognathism, a hypoplastic maxilla and mandible and a highly retrognathic profile. Intraoral findings include a grooved palate, dental crowding, overly retained deciduous teeth and delayed eruption of permanent dentition, tooth misalignment, enamel hypoplasia. The development of severe dental caries, obliterated pulp chambers and periodontal diseases have also been described. 
All these findings, especially the intraoral findings, were consistent with the present case reports $(1-3,8)$.

The diagnosis of pycnodysostosis is primarily based on clinical features and radiographs, but the confirmatory test is a cathepsin $\mathrm{K}$ gene mutation analysis. During the 1990s, the genetic defect was located on chromosome 1q21, which led to specific genetic testing and accurate diagnosis. A mutation in the gene that codes for the enzyme cathepsin $\mathrm{K}$ inhibits the normal function of the osteoclasts. Other uncommon clinical disorders of reduced bone resorption include osteopetrosis, osteogenesis imperfecta, cleidocranial dysplasia and idiopathic acroosteolysis. In fact, in pycnodysostosis, the number of osteoclasts is normal but the region of demineralized bone surrounding them is larger than normal. Recognition of these signs is important in order to make the diagnosis and prevent possible complications $(2-4,8)$.

PKND patients usually have a normal life span. Bone fragility and a history of frequent fractures may suggest a diagnosis of abnormalities in the material composition and structure of bone. Early diagnosis can ensure a better life quality, which require proper attention to risk factors during treatment planning. Unfortunately, PKND patients need dental care later in life, having missed early childhood prevention of oral disease. Early intervention to qualify dental crowding has been recommended to the pediatric patient to allow better dental alignment and oral hygiene of the primary and erupting permanent dentition reducing chances of dental impaction, periodontal disease, and dental caries $(1,3,6)$. In the present study, almost all intraoral features of PKND such as dental crowding, dental caries, periodontal diseases, persistence of deciduous teeth observed, the congenital absence of many permanent teeth were observed.

Enamel hypoplasia was mentioned in the literature as one of the alterations commonly found in patients with pyknodysostosis. However, the patients of this report did not present signs of alterations in the enamel or in the shape of teeth. Furthermore, alteration was noted in the tooth eruption, similar to the report of Hunt et al, who observed a delay in eruption (12). According to the literature both Class II and Class III malocclusions are in association with PKND. Norholt et al. stated that these patients often present a Class III dentition owing to the maxillary hypoplasia (13). Presented patients have dental Class III malocclusion.

There is no specific treatment for this anomaly and the current treatment options for dental caries is only restorative or protective treatments. Recommendations or information about the effective and reliable orthodontic treatment of children or young adults with pycnodysostosis are not available in the literature. Orthodontic and orthopaedic movements are dependent on osteoclastic activity, bone resorption and remodeling capacities. Because of high risk of fracture and low remodeling capacity orthognathic surgery and orthodontic treatment have not been previously described for PKND affected patients. Only in one recent case report distraction osteogenesis technique was used $(2,10,13)$. Taking into consideration the fragility in our patients, appropriate restorative treatments and protective applications were preferred, but orthodontic treatment could not be carried out. Patients were given oral hygiene education and recall visits is occured in 3-months period.

Tooth extraction in patients with pycnodysostosis is carried out during surgery as atraumatically as possible to reduce the risk of fracture, especially in the mandible. However, post-extraction osteomyelitis may develop because of the increased bone density $(1,14)$. It is important with such patients to bear in mind the increased risk of pathological fractures during dental operations and tooth extraction because of bone fragility. However, in spite of the fragility, bone healing is normal (4).

In this study, three of the siblings carry L7P variation of the gene, whereas healthy siblings had the same variation as heterogeneous. $\mathrm{T}>\mathrm{C}$ transition at exon 2 leads the change of the amino acid leucine $(\mathrm{L})$ to amino acid proline $(\mathrm{P})$. This amino acid change is considered to affect the signal peptide sequence of protein, as indicated in other studies (15).

Many have reported on clinical and radiological findings associated with this syndrome; however, only a few have added their restorative treatments and genetic investigation to their reports. In this case report we did appropriate restorative treatments and protective applications to the patients. Because of serious limitations imposed by dentofacial discrepancies, it would be advisable for PKND patients to be treated as high-risk patients with frequent recall visits in order to prevent dental caries and periodontal disease, providing early intervention if restorative procedures become needed (9).

\section{Concusion}

The dentists should recognize the radiographic and clinical maxillofacial features of pycnodysostosis, which allows correct treatment planning avoiding risks and ensuring better 
treatment plan for PKND patients. The ideal approach to the management of gingival, dental and craniofacial problems associated with PKND should be multidisciplinary, involving the pediatric dentist, orthodontist and oral and maxillofacial surgeon. Early diagnosis and treatment is important with PKND patients, since bone fractures easily occur during dental treatment and limited mouth opening makes it difficult to access the treated area. Child patients with pyknodysostosis should receive special dental care, particularly preventive treatment, because of the group of mouth alterations described, in addition to periodical follow-up of their growth and craniofacial development. Frequent recalls should be planned for all PKND patients. Regular oral care and early preventive treatments ensure the patients a better life quality. Conclusively, we suggest that L7P mutation may be a diagnostic criteria for this anomaly, but extended number of studies is needed to fulfill the role of this gene on the onset of the anomaly.

\section{References}

1. Hernández-Alfaro F, Arenaz Búa J, Serra Serrat M, Mareque Bueno J. Orthognathic surgery in pycnodysostosis: a case report. Int J Oral Maxillofac Surg. 2011; 40(1):110-113.

2. Barnard B., Hiddema W. Pycnodysostosis with the focus on clinical and radiographic findings. Afr J Rad. 2012;16(2):74-76.

3. Alakus Sabuncuoglu F, Ölmez H. Craniofacial And Intraoral Evaluation Pycnodysostosis: (A Case Report). J Dent Faculty Atatürk Uni. 2012; 5:24-28.

4. Soares LF, Souza IP, Cardoso AS, Pomarico L. Pyknodysostosis: oral findings and differential diagnosis. J Indian Soc Pedod Prev Dent. 2008; 26: 23-5.

5. Ahmet Arman, Abdullah Bereket, Ajda Coker, Pelin Özlem Şimşek Kiper, Tülay Güran, Behzat Özkan, Zeynep Atay, Teoman Akçay, Belma Haliloglu, Koray Boduroglu, Yasemin Alanay, Serap Turan. Cathepsin K analysis in a pycnodysostosis cohort: demographic, genotypic and phenotypic features. Orphanet $\mathrm{J}$ Rare Dis. 2014; 26;9:60, doi:10.1186/1750-1172-9-60.

6. Kafienah W, Bromme D, Buttle DJ, Croucher LJ, Hollander AP. Human cathepsin $\mathrm{K}$ cleaves native type I and II collagens at N-teminal end of the triple helix. Biochem J. 1998;331:727-732.

7. Xue Y, Cai T, Shi S, Wang W, Zhang Y, Mao T, Duan X. Clinical and animal research findings in pycnodysostosis and gene mutations of cathepsin K from 1996 to 2011. Orphanet J Rare Dis. 2011;6:20.

8. Kamak H, Kamak G, Yavuz I. Clinical, radiographic, diagnostic and cephalometric features of pycnodysostosis in comparison with Turkish cephalometric norms: A case report. Eur J Dent. 2012; 6(4):454-459.

9. Alves N, Cantín M. Clinical and radiographic maxillofacial features of pycnodysostosis. Int J Clin Exp Med. 2014; 7(3):492-496.

10. Alves Pereira D., Berini Aytés L, Gay Escoda C. Pycnodysostosis. A report of 3 clinical cases. Med Oral Patol Oral Cir Bucal. 2008; 1;13(10):E633-5.

11. Fonteles CS, Chaves CM Jr, Da Silveira A, Soares EC, Couto JL, de Azevedo Mde F. Cephalometric characteristics and dentofacial abnormalities of pycnodysostosis: report of four cases from Brazil. Oral Surg Oral Med Oral Pathol Oral Radiol Endod. 2007; 104(4):e83-90.

12. Hunt NP, Cunninghan SJ, Adnan N, Harris M. The dental, craniofacial, and biochemical features of pyknodisostosis: A report of three new cases. J Oral Maxillofac Surg. 1998; 56:497-504.

13. Norholt SE, Bjerregaard J, Mosekilde L. Maxillary distrac tion osteogenesis in a patient with pycnodysostosis: a case report. J Oral Maxillofac Surg. 2004;62:1037-1040.

14. Landa S, Esteban S, Montes E, Santamaria J, Vitoria A, Santolaya JM. Maxillofacial alterations in a family with pyc - nodysostosis. Med Oral. 2000;5:169-176.

15. Donnarumma M, Regis S, Tappino B, Rosano C, Assereto S, Corsolini F, Di Rocco M, Filocamo M. Molecular analysis and characterization of nine novel CTSK mutations in twelve patients affected by pycnodysostosis. Hum Mutat. 2007; 28(5):524. 